\title{
THE BATTLE FOR TRUTH: CONTROL AND NON-VOTING PREFERENCE SHARES
}

\author{
Daryl A Dingley and Phumlani MP Ngcongo \\ Competition Law Department, Webber Wentzel \\ Paul BJ Farlam \\ High Court of South Africa \\ Jeremy C Marwell
}

JEL G34, L41

\section{1}

\section{Introduction}

If a financial institution (A) advances funding to another company (B) in return for non-voting preference shares in company B at par value, does that constitute a merger for the purposes of s 12 of the Competition Act, 89 of 1998 (the Act), if those preference shares comprise more than 50 per cent of the issued shares (ordinary and preference) of company B? And what if company B's articles of association provide that the holder of the preference shares may obtain a right to vote at shareholders' meetings if any preference dividend is not paid timeously, or if the preference shares are not redeemed within the agreed time? Would a provision to that effect play any role in an assessment as to whether the initial transaction constituted a merger and/or requires a further merger notification upon the triggering of company A's right to vote?

These were the interesting questions which the Competition Tribunal (the Tribunal) had to address in Cape Empowerment Trust Ltd v Sanlam Life Insurance Ltd and another ${ }^{1}$ (CET v Sanlam). (The losing party, Cape Empowerment Trust Ltd (CET), took the matter on appeal, but the parties settled after the case had been argued in the Competition Appeal Court (CAC), but before judgment had been delivered).

To contextualise the issues discussed in this paper, we begin by briefly outlining the facts of that case, the main submissions of the parties, and the findings of the Tribunal. We will then analyse the main issues arising for consideration in relation to the scenario sketched in the opening paragraph of this paper, again with reference to the parties' submissions and the Tribunal's determination in CET v Sanlam. By way of comparison, we will also refer to foreign law, particularly United States anti-trust law.

\section{2}

\section{The CET v SANLAM case}

On 13 March 1998, the legal predecessor to Sanlam Life Insurance Limited (Sanlam) and a Western Cape-based empowerment company, Sancino Projects Ltd (Sancino), entered into a written agreement in which Sanlam subscribed in cash for 10 million redeemable preference shares in the share capital of Sancino with a par value of 1c (with Sancino's issued share capital being increased by the same amount). The shares were issued and allotted by Sancino to Sanlam at a premium of R0.99 per preference share, and were thus subscribed to by Sanlam for R10 million.

As the Tribunal noted ${ }^{2}$, Sanlam, which is one of South Africa's largest listed life assurance companies, is a significant investor in unlisted projects. Sancino, in need of a cash injection in 1998 after some failed investments, was such a project. The present transaction effectively entailed Sanlam advancing R10 million to Sancino, and, in consideration, receiving 10 million redeemable preference shares, redeemable after four years, in March 2002.

Immediately prior to the conclusion of the agreement, Sanlam was the beneficial owner of 354192 ordinary shares in Sancino's issued share capital, which then comprised about 3.53 
million ordinary shares with a par value of $1 \mathrm{c}$ each. Sanlam thus owned approximately 10 per cent of the issued share capital in Sancino before the issue of the 10 million preference shares. After being issued with the preference shares in March 1998, Sanlam became the beneficial owner of about 76.4 per cent of Sancino's issued share capital.

The preference shares had the rights and privileges set out in the agreement between Sanlam and Sancino (the agreement), as read together with article 109 of the articles of association of Sancino (the Articles). The most important of those rights and privileges were the conditional voting rights. In terms thereof, Sanlam had the right to vote its preference shares at any of the meetings of Sancino only if any one or more of three circumstances prevailed at the date of the meeting: (i) the preference dividend or any part there of remained in arrears and unpaid 30 days from the due date thereof; (ii) any redemption payment remained in arrears and unpaid 30 days from the due date; or (iii) a resolution of the company was proposed which directly affected any of the rights attached to the preference shares or the interests of the holders thereof.

In terms of the agreement, preference dividends had to be declared on the last day of February each year and were payable on the last day of May in each year, commencing with effect from 31 May 1999. The redemption payment had to be made by March 2002.

Sancino did not pay preference dividends to Sanlam in accordance with the agreement. Further, Sancino did not redeem Sanlam's preference shares on the fourth anniversary of the subscription date (namely, 13 March 2002). As a result, Sanlam had the right to vote its preference shares on the same basis as ordinary shareholders at any Sancino members' meetings from at least March 2002. Sanlam was, however, prepared to continue playing a passive role for a number of years. During this time, Sancino's indebtedness to Sanlam continued to increase. By January 2006, it had grown to approximately R23 million.

Notwithstanding its financial obligations to Sanlam, Sancino was an attractive company by virtue of its minority stake in a company which had a shareholding in the GrandWest Casino in Cape Town. CET, an investment-holding company listed on the JSE, accordingly acquired a significant minority holding in Sancino in 2005 , and made plans to obtain a controlling interest.

In October 2005, CET made an offer to the ordinary shareholders of Sancino to acquire all their shares in Sancino at a ratio of seven CET shares for each Sancino share. The offer was well received by some Sancino shareholders, but not by the Sancino board, which, on 28 October 2005, issued a circular to the shareholders informing them that the board did not consider the offer acceptable. Sancino's board also rejected a revised CET proposal in December 2005. Sanlam, too, was opposed to CET's offers.

Sancino's board formulated a proposal of its own, and, on 16 January 2006, notified Sancino's shareholders that a special meeting of shareholders was being convened on 8 February 2006 to vote on a number of special resolutions. The effect of these resolutions would be to discharge Sancino's liability to Sanlam by issuing to Sanlam 2.364 million ordinary shares in Sancino in settlement of the outstanding preference dividend (of R13 million), and by converting Sanlam's 10 million preference shares into 1.818 million ordinary shares.

CET's response was to call for a meeting of Sancino's shareholders on 7 February 2006 to consider certain resolutions to be tabled by CET. The resolutions involved, inter alia, Sancino borrowing R20 million from CET to redeem in whole or in part Sanlam's preference shares in Sancino.

In the event of the resolutions to be put to the vote on 7 February 2005 being passed and implemented, Sanlam's chances of converting its preference shares to ordinary shares, pursuant to the 8 February resolutions, would be nullified. But, in reality, CET had little chance of having its 7 February resolutions carried if Sanlam were permitted to vote all its ordinary and preference shares. CET accordingly applied to the Tribunal for an urgent interdict to prevent Sanlam from exercising its voting rights at the 7 and 8 February meetings. CET argued that it was entitled to the interdict because, if Sanlam were 
to exercise its voting rights, it would constitute the implementation of a merger that had not been approved by the competition authorities.

In essence, CET argued that: (i) there was a change of control when Sanlam obtained the right to vote its preference shares in Sancino in March 2002 as a result of the redemption of Sanlam's preference shares and payment of its preference dividends being overdue; (ii) this change of control in March 2002 constituted a merger (between Sanlam and Sancino) as defined in s 12(1)(a) of the Competition Act, and that, as it was a large or intermediate merger, the Competition Commission (the Commission) had to be notified thereof; (iii) neither Sanlam nor Sancino had notified the Commission of the merger; nor had the merger been approved by the Tribunal or the Commission; and (iv) accordingly, the merger could not be implemented, which meant, inter alia, that Sanlam was precluded even from exercising voting rights in respect of its preference shares.

Sanlam, in response, replied that, with the issue to Sanlam of the preference shares in March 1998, Sanlam became the beneficial owner of more than half of Sancino's issued share capital. It had thus acquired control of Sancino as contemplated in s 12(2)(a) of the Competition Act. The Competition Act does not apply retrospectively to an acquisition of control which occurred in March 1998. Accordingly, no notification of that merger was required when the relevant provisions of the Competition Act came into force on 1 September 1999. Furthermore, Sanlam said, because it had acquired control in March 1998, the accretion of voting rights in March 2002, although a different form of control (s 12(2)(b)), did not result in a fresh acquisition of control (as control had already existed).

The Tribunal agreed with Sanlam's contentions, which were also supported by Sancino (the second respondent before the Tribunal).

The Tribunal found, first, that Sanlam had controlled Sancino from March 1998 (i.e. prior to the commencement of the Competition Act) by virtue of owning more than half the issued share capital in Sancino. Its finding on that issue is summarised in paragraph 56 of the Tribunal's determination:
As the owner of the preference shares Sanlam owned more than half the issued share capital of Sancino, being the sum of the par value of its ordinary and preference shares. Taking account of the specific circumstances of Sancino's capital structure, this satisfies the definition of control in section 12(2)(a) of the Act. This state of affairs predated the entry into force of Chapter 3 of the Act and accordingly it was not incumbent on Sanlam and Sancino to file a notification of this relationship with the competition authorities when the Act came into force.

Secondly, the Tribunal found that the position did not change with the acquisition of voting powers by Sanlam in Sancino as a result of the repeated defaults by Sancino. According to the Tribunal $^{3}$

[t]here was no change of control [when Sanlam acquired voting powers over a majority of the issued share capital upon the occurrence of Sancino's defaults], but merely the superimposition of another one or more forms of control contemplated by the Act. No additional potential threat to competition came into being when Sanlam gained the majority voting rights in Sancino. Notification in those circumstances would have been otiose.

\section{3}

\section{Non-voting preference shares and control}

As we have indicated, the first question that arises when a company acquires non-voting preference shares on a scale akin to Sanlam's acquisition in Sancino is whether there has been a change of control, and thus a notifiable merger, at that time. That is the primary question we address in this paper.

The second question concerns whether there would be a further notification requirement in the event that the conditional voting rights are triggered in respect of those preference shares ${ }^{4}$. We will consider that question as well, albeit in less detail. 
The relevant statutory provision in respect of both issues is $\mathrm{s} 12$ of the Competition Act. It may assist if we quote it at this point.

Merger defined

(1) (a) For purposes of this Act, a merger occurs when one or more firms directly or indirectly acquire or establish direct or indirect control over the whole or part of the business of another firm.

(b) A merger contemplated in paragraph (a) may be achieved in any manner, including through -

(i) purchase or lease of the shares, an interest or assets of the other firm in question; or

(ii) amalgamation or other combination with the other firm in question.

(2) A person controls a firm if that person -

(a) beneficially owns more than one half of the issued share capital of the firm;

(b) is entitled to vote a majority of the votes that may be cast at a general meeting of the firm, or has the ability to control the voting of a majority of those votes, either directly or through a controlled entity of that person;

(c) is able to appoint or to veto the appointment of a majority of the directors of the firm;

(d) ....;

(e) $\ldots$;

(f) $\ldots$; or

(g) has the ability to materially influence the policy of the firm in a manner comparable to a person who, in ordinary commercial practice, can exercise an element of control referred to in paragraphs (a) to (f).
4

\section{Whether the purchase of non-voting preference shares constitutes the acquisition of control}

\subsection{The South African approach}

As the CAC stated in Distillers Corporation (SA) Ltd v Bulmer (SA) (Pty) Ltd ${ }^{5}$ (Distillers v Bulmer), s 12(2) provides a non-exhaustive list of examples of the change of "control" referred to in s 12(1)(a). Thus, when, as in CET v Sanlam, a company acquires more than 50 per cent of the issued shares in another, one first looks to see whether the transaction fits into one of the categories listed in s 12(2), in order to determine whether there has been a direct or indirect acquisition of control.

The s 12(2) category, which immediately comes to mind in a case like CET $v$ Sanlam is $\mathrm{s}$ 12(2)(a), which refers to there being control in the event of a person beneficially owning "more than one half of the issued share capital of the firm". But what exactly does the phrase "issued share capital" cover in this context? More particularly, does it include non-voting redeemable preference shares? And what if the transaction falls within the plain meaning of the words in s 12(2)(a) but does not appear to involve any actual change of control? Should s 12(2)(b) be "read down" in such circumstances, thus effectively requiring notification only when there are actual instances of changes of control?

In CET v Sanlam, CET accepted that, in ordinary commercial parlance, the share capital of a company includes both ordinary and preference shares (citing s 74 of the Companies Act, 61 of 1973 as authority). In other words, CET's counsel accepted that the phrase "issued share capital" in s 12(2)(a) of the Competition Act included all issued shares, including nonvoting preference shares.

In our view, that concession was clearly right.

In South African company law, the term "issued share capital" means, as the words suggest, all shares issued by the company, or, in other words (because, in terms of s 92(1) of the 
Companies Act, a company cannot issue partly paid-up shares) something equivalent to the company's paid-up share capital ${ }^{6}$.

A company's share capital includes its ordinary and preference shares. The term "preference share" is not defined in the Companies Act. It is simply a term which has become embedded in commercial language to describe a share to which some kind of preferential right to dividends and/or a return of capital on liquidation is accorded. The nature of these preferential rights and the limitations that sometimes accompany them differ widely. It depends entirely on the rights determined by the company when exercising its power to create different classes of shares? The qualified exclusion of voting rights is a permissible but not necessary feature of preference shares ${ }^{8}$.

It is clear from the use of the term "preference share" in the Companies Act that preference shares are regarded as forming part of the company's share capital. For example, ss $75(1)(f)$ and $(g)$, in dealing with alterations in share capital, speak of the conversion of the company's "ordinary or preference share capital". Section 98 states that a company that has a "share capital" may issue redeemable preference shares. Schedules 3 and 4 of the Companies Act, specifying the disclosure concerning share capital to be made in prospectuses and financial statements, take it for granted that preference shares are part of share capital and must be disclosed as such ${ }^{9}$. For example, item 9 of Schedule 4 regulates disclosure concerning "any part of the issued share capital that consists of redeemable preference shares".

The definition of "equity share capital" in $\mathrm{s} 1$ of the Companies Act alludes to preference shares without actually using that term. From the definition it is clear that preference shares form part of share capital, with "equity share capital" constituting a subset of share capital. See, too, the Tribunal's comments at par 48 of its determination in CET v Sanlam).

CET argued, however, that s 12(2)(a) should not be interpreted in isolation both from s 12(1)(a) and from Chapter 3 of the Competition Act, generally. With reference to the judgment of the CAC in Distillers v Bulmer, CET's counsel argued that $\mathrm{s} 12(2)$ is intended to elucidate and instance circumstances of the concept of "control" in s 12(1)(a), and that s 12(2)(a) is not intended to affect transactions in which the acquirer of shares never intended exercising control or indeed playing any active role in the company in question. More particularly, s 12(2)(a) was not, so CET submitted, intended to apply to the issuing of non-voting preference shares as a funding instrument. What CET's argument effectively amounted to was that s 12(2)(a) should be read restrictively, through the prism of s 12(1).

Those submissions could well accord with the way certain funding institutions regard any preference share-based funding structures with which they are involved. According to Blackman et al in Commentary on the Companies Act ${ }^{10}$, preference shares in South Africa are primarily funding instruments, properly regarded as akin to debentures. CET's arguments possibly reflect how Sanlam and Sancino initially regarded the transaction, that is, as a way of providing funding to enable Sancino to discharge a portion of the debts it had incurred in respect of a printing business that it owned, while providing Sanlam with maximum security.

In addition, CET's approach has a certain intuitive appeal. Company lawyers are, in general, unlikely to talk of a shareholder exercising control of a firm when the shares through which it seeks to exercise that control do not enjoy voting rights. CET's contentions may consequently also, at first sight, be seen as consistent with the purpose and objects of $\mathrm{s} 12$ of the Competition Act, in particular the apparent purpose of s 12(1) (the dominant provision in the section).

But, in our view, s 12(2) of the Competition Act ultimately permits of no other interpretation than that reached by the Tribunal in CET $v$ Sanlam. There are, moreover, a number of factors supporting the Tribunal's interpretation, notwithstanding the apparent incongruity of the notion of control which infuses s 12(1). We say this for a number of reasons.

First, the ordinary commercial meaning must surely be adopted when interpreting s 12(2)(a) of the Competition Act. In the absence of any definition of the term "issued share capital", the words should be given their usual meaning. 
Secondly, the fact that the issuing of preference shares might be a way of raising capital for a company (as indeed the issuing of ordinary shares can be) also does not mean that the issuing of preference shares to Sanlam should properly be categorised as a loan. As the Tribunal held in CET v Sancino ${ }^{11}$, it would have to be found that the agreement in that case involved "a sham or disguised transaction" in order to get past the fact that Sanlam subscribed for preference shares in Sancino in March 1998; it did not make a "loan akin to a debenture". And there is no basis for reaching such a conclusion: "[o]n every criterion known to the Tribunal the preference share issue, in this case, was a real one, conforming to customary norms for preference shares"12, 13

Another consideration is that of practicality. A person who beneficially owns more than one half of a company's issued share capital may not immediately or permanently have voting rights, but the legislature would have been aware that shares (particularly preference shares) may accord voting rights if particular circumstances arise. Such a shareholder might acquire and then lose such voting rights intermittently. It would be wholly impractical to view each acquisition of voting rights and each cessation of voting rights as involving a notifiable merger. As a matter of practicality, the transaction could only really be notified at the outset, upon conclusion of the agreement and subscription for the shares.

The facts underlying CET $v$ Sancino usefully illustrate this. As the agreement in CET v Sancino contemplated, the company (Sancino) could be in default at various times during the currency of the agreement - as Sancino in fact was. If a merger was regarded as occurring and was notifiable only when the preference shareholder's (Sanlam's) voting rights could be exercised, there could consequently be repeated notifications, and mergers would be constituted or dissolved at any time (notwithstanding the same agreement and share ownership being in place). In other words, there would be what was referred to in the Tribunal's decision as "the problem of "see-sawing". ${ }^{14}$ What would make that scenario even more unworkable is that Sanlam would be required to notify the Tribunal in circumstances where Sancino could potentially have cured the default by the time that the Tribunal came to consider whether the triggering of Sanlam's right to vote (by no voluntary act on its part) raised any competition concerns.

It would moreover be untenable for the purchaser of preference shares in a company not to know whether its subscription for those shares was acceptable to the competition authorities until such time as the company was in default with its obligations. A party in the position in which Sanlam found itself in CET $v$ Sanlam would have a very real interest in obtaining merger approval prior to the implementation of the agreement. Voting rights in the event of the company's default are conferred on preferent shareholders precisely to enable them to exercise control in periods when their interests require particular protection. The voting rights constitute an important protective mechanism without which the preferent shareholder might well not be willing to subscribe. Before implementing the transaction, that shareholder is thus entitled to know that the potential control for which the agreement makes provision has competition approval. It cannot be expected to run the risk at a later stage of losing an important quid pro $q u o$ for which it bargained (namely, voting power in the event of default by the company whose shares had been subscribed for).

Furthermore, practical considerations should not be thought irrelevant to interpretation. The legislature should not easily be taken to have intended an unbusinesslike interpretation. The legislature should also be taken to have been aware that preference shares are extremely common in the commercial world. That being so, it is sensible to accord s 12(2)( $a$ ) its ordinary meaning and to treat it as applying inter alia to shares which may from time to time accord the holder voting control ${ }^{15}$.

Moreover, interpreting the words "issued share capital" in the way that the Tribunal did in CET v Sancino is consistent with s 12(2) of the Competition Act as a whole. That section draws a distinction between owning more than half of the issued share capital of a firm (addressed in $\mathrm{s} 12(2)(a)$ ) and being entitled to vote a majority of the votes that may be cast at a general meeting of the firm (a power addressed in s 12(2)(b)). 
The Competition Act accordingly contemplates a situation in which firm A beneficially owns more than 50 per cent of the issued share capital of firm B but does not have the right to vote more than 50 per cent of the votes that may be cast at a general meeting of the latter. The Competition Act indicates that, even in those circumstances, firm A will be regarded as controlling firm $\mathrm{B}$.

The Tribunal explained the rationale for distinguishing between ownership and voting rights in the context of merger definitions in Ethos Private Equity Fund IV / Tsebo Outsourcing Group (Pty) Ltd ${ }^{16}$ (the Ethos case) and Caxton and Another $v$ Naspers Ltd and Others (Caxton $v$ Naspers $)^{17}$. As the Tribunal stated in Caxton $v$ Naspers at par. 29:

In Ethos the Tribunal explained why merger policy is not confined to an assessment of control via the legal form. We made the point that control can also be exercised by virtue of a party's economic leverage over another and that this formed the rationale for the language of section 12(2)(a) which emphasises ownership of shares as something distinct from voting rights.

The Tribunal also held in the Ethos case ${ }^{18}$ that a firm which acquires more than 50 per cent of the issued share capital of another firm obtains control of the latter, notwithstanding a shareholders' agreement or any other constraint which limits the voting power of the majority shareholder. Where the "bright line" in s 12(2)(a) of the Competition Act is crossed, notification is necessary, irrespective of whether any other incidents of control are present ${ }^{19}$.

As the Tribunal noted in its reasons in CET $v$ Sanlam $^{20}$, the CAC's judgment in Distillers $v$ Bulmer is to the same effect. In that case, the Court held that the Competition Act contemplates more than one type of control, and that more than one firm can accordingly "control" another at any time ${ }^{21}$. To use the example postulated in Distillers, where A beneficially owns more than half of the issued share capital of a firm, but concludes an agreement with B in terms of which the latter can run the business and control appointments to the board of directors, both $\mathrm{A}$ and $\mathrm{B}$ exercise control for the purposes of $\mathrm{s} 12$ of the Competition Act. As Davis JP stated at 46c: "In such a situation A would control the firm as defined in terms of section 12(2)(a) and $B$ would exercise control as defined in term $[\mathrm{s}]$ of section 12(2)(g)".

When examined closely, there also may well be nothing contrary to the purpose of s 12 of the Competition Act in interpreting s 12(2)(a) the way it was interpreted in CET $v$ Sanlam.

As the CAC held in Distillers at $45 \mathrm{~h}$,

the Act was designed to ensure that the competition authorities examine the widest possible range of potential merger transactions to examine whether competition was impaired and this purpose provides a strong pro-pointer in favour of a broad interpretation to section 12 of the Act $^{22}$.

The Competition Act thus creates a regime in which even potentially innocuous transactions are scrutinised by the competition authorities. But that over-inclusive approach was no doubt, for good reason, considered better than an under-inclusive one in which transactions with potentially anti-competitive effects might go undetected and unchecked.

Moreover, as the Tribunal noted in Caxton ${ }^{23}$, $\mathrm{s} 12$ is not confined to an assessment of control via the legal form; it is also concerned with a party's economic leverage over another. This is confirmed not only by the incidents of control specified in s 12(2), but also by the fact that $\mathrm{s} 12(1)(\mathrm{a})$ refers to a merger occurring even when one firm indirectly acquires indirect control over another firm ${ }^{24}$. A firm that owns the majority of another firm's issued share capital has such economic leverage, whether its shareholding involves ordinary or preference shares, or, as in the present case, a combination of both. There can also be no doubt that Sanlam has, since subscribing for its preference shares, been in a position of some power and influence vis-à-vis Sancino. (That influence has only increased as Sancino's indebtedness to Sanlam increased over the years).

Thus, in our view, the Tribunal was correct in finding in CET $v$ Sanlam that there was a merger in that case in March 1998, when Sanlam 
became the beneficial owner of over 76 per cent of Sancino's issued share capital. The wording of s 12(2) of the Competition Act permitted of no other interpretation; and, in any event, CET provided no workable alternative.

That said, one is nonetheless left with a certain unease about the potential costs of the Tribunal's decision in CET v Sanlam and the potentially chilling effect it will have on certain kinds of corporate financing, not only with regard to non-voting preference shares, but possibly also debentures and certain kinds of secured transactions, venture capital funding, and the like.

In fact, the Tribunal itself was careful to say ${ }^{25}$ that:

[it] should be stressed that our findings in this case - the first in which we have had to consider the role of preference shares in the share capital of a company - are confined to the circumstances of this case, and are not necessarily the last word of the Tribunal on the broader topic of control in terms of issued share capital. Each case will have to be assessed on its own merits.

Quite what made the Sanlam / Sancino transaction different from others involving the issuing of non-voting preference shares to a financial institution was not spelt out. It may well be difficult to distinguish that decision meaningfully in subsequent cases. But the Tribunal's unease about the ramifications of its decision (in relation to a matter which it considered to have "a considerable degree of complexity"26) was clearly apparent, and quite possibly justified.

The Tribunal ruling in CET $v$ Sanlam may, for example, require a reconsideration of the Commission's stance on other forms of funding, notably when a bank acquires an asset or a controlling interest in a firm in the ordinary course of its business in providing finance based on collateral or security. The Commission previously indicated in an advisory notice to practitioners that, in those circumstances, it does not require notification at the time of entering into the transaction, or, in fact, immediate notification on default ${ }^{27}$. Such "safe harbour" provisions might now need to be revisited. On one hand, a strict application of the Tribunal's rule in CET v Sanlam (that a non-voting interest can establish control) might suggest that the bank safe harbour should be eliminated. On the other, however, a potential expansion in the nature and number of transactions that are notifiable in the wake of CET $v$ Sanlam might suggest an increased practical need for this (and other) safe harbours.

Given the possible practical ramifications of the CET v Sanlam decision, in particular, it is interesting to look at how the same issue is treated in foreign jurisdictions. Section 1(3) of the Competition Act provides that "[a]ny person interpreting or applying this Act may consider appropriate foreign and international law". Comparative law could thus provide some guidance as to the advisability of the South African approach, as well as possible alternative approaches which could be adopted in the event of the South African legislation being out of kilter with developments in the rest of the world.

\subsection{Comparative approaches}

There is some evidence of a potentially different approach in the European Union and Canada.

The Commission Notice on the Concept of Concentration under Council Regulation (EEC) No. 4064/89 on the Control of Concentrations between Undertakings ${ }^{28}$ provided:

Sole control is normally acquired on a legal basis when an undertaking acquires a majority of the voting rights of a company. It is not in itself significant that the acquired shareholding is 50 per cent of the share capital plus one share or that it is 100 per cent of the share capital. In the absence of other elements, an acquisition which does not include the majority of the voting rights does not normally confer control even if it involves the acquisition of the majority of the share capital.

That approach would appear to be consistent with the emphasis on "decisive influence" in the context of merger notifications in EU competition law ${ }^{29}$. Under EU competition law, it is recognised that the acquisition of control may 
be in different forms, but that it is the ability to exercise decisive influence that is paramount in determining whether control has been acquired. Accordingly, when confronted with an option to convert or purchase shares, the EU authorities have held that control is conferred only at the point of the option being exercised ${ }^{30}$, unless there is an agreement that the option will be exercised in the immediate future in accordance with a legally binding agreement that cannot be revoked by the parties. Thus, for example, in British Airways / TAT ${ }^{31}$, British Airways acquired 49 per cent of the share capital of TAT and was granted an option to purchase the remaining 50.1 per cent held by TAT. TAT, in turn, was granted an option to require British Airways to do so before a specific date. In analysing the transaction, the EC Commission concluded that British Airways exercised joint control with TAT as a consequence of the shareholding structure provided in the shareholder's agreement. The EC Commission disregarded the potential second acquisition of sole control that would have been conferred on BA by virtue of the option. Clearly, the EC Commission relied on the point at which the (joint) control was acquired and not the future potential to acquire sole control in terms of the option.

As far as Canada is concerned, some guidance as to the relevant rules is provided by the Interpretation Guideline on Notifiable Transactions under Part IX of the Canadian Competition Act, which states:

Acquisitions of non-voting shares of a corporation are not notifiable under Part IX of the Act. Thus, where non-voting shares are being acquired from a third party holding them and reflecting them on its balance sheet as assets, the acquisition is not notifiable.

In the case of an acquisition of convertible securities, such as convertible debentures, convertible non-voting shares, options, warrants and rights, notice of acquisition need only be given where the securities will be converted to voting shares ....

There is consequently a basis for thinking that, in Europe and Canada, the kind of transaction considered in CET v Sanlam would not have been notifiable. The European and Canadian documents considered above do not, however, by themselves provide a basis for suggesting how those regions would approach a case such as CET v Sanlam, or warrant any definitive conclusions being drawn about the approach adopted to acquisitions involving non-voting shares.

To be of any real assistance, a more comprehensive analysis is required, something that we have conducted in relation to United States anti-trust law.

\subsection{US regulatory background}

By way of very brief background, US anti-trust law involves several overlapping statutory and regulatory regimes, including, at the federal level, the Sherman $\mathrm{Act}^{32}$, the Clayton $\mathrm{Act}^{33}$ and the Hart-Scott-Rodino Antitrust Improvements Act of 1976 (the HSR Act) ${ }^{34}$, as well as the antitrust and competition laws of the 50 individual states.

The Clayton Act is the primary federal statute governing competition issues raised by mergers and acquisitions. It prohibits acquisitions where "the effect of such acquisition may be substantially to lessen competition, or to tend to create a monopoly" ${ }^{35}$. The Sherman Act prohibits unreasonable restraints of trade, attempts to monopolise, and monopolisation. The HSR Act governs procedural aspects of the review of mergers and acquisitions. It gives two federal agencies-the Antitrust Division of the US Department of Justice and the Federal Trade Commission (FTC) - the opportunity to assess anti-trust issues posed by proposed transactions before those transactions are consummated. For transactions meeting certain jurisdictional thresholds (e.g., transaction value), the HSR Act requires parties to file a notification and allow a waiting period to elapse before completing the transaction $^{36}$.

While all mergers and acquisitions, regardless of size, are subject to the Clayton Act, transactions falling within the HSR Act's jurisdictional provisions are far more likely as a practical matter to be scrutinised by the reviewing agencies. 
We thus commence by using the HSR Act as a starting point for a comparison with CET $v$ Sanlam. We will then examine the impact of the Clayton Act, and whether acquisitions of the kind considered in CET v Sanlam would be subject to the provisions of that statute.

\subsection{The HSR Act and non-voting shares}

The plain text of the HSR Act is potentially ambiguous about whether an acquisition of non-voting preference shares triggers that Act's notification and waiting requirements. The statute provides:

[e]xcept as exempted pursuant to subsection

(c) of this section, no person shall acquire, directly or indirectly, any voting securities or assets of any other person, unless both persons (or in the case of a tender offer, the acquiring person) file notification [with the relevant agency] ... and the [statutorilydefined] waiting period ... has expired ${ }^{37}$.

The Act further defines "voting securities" as: any securities which at present or upon conversion entitle the owner or holder thereof to vote for the election of directors of the issuer or, with respect to unincorporated issuers, persons exercising similar functions. ${ }^{38}$

But the Act then specifically exempts acquisitions of bonds, mortgages, deeds of trust, or other obligations which are not voting securities from the HSR Act's reporting and waiting period requirements. ${ }^{39}$

The FTC's HSR regulations specify, however, that acquisitions of shares that do not currently carry voting rights are exempt from the HSR Act's reporting and waiting period requirements. In particular, 16 C.F.R. $\$ 802.31$ (2007) states that "[a]cquisitions of convertible voting securities shall be exempt from the requirements of the Act". According to an explanatory note to the regulation, this exemption "applies regardless of the dollar value of the convertible voting securities held or to be acquired" but "subsequent conversions of convertible voting securities may be subject to the requirements of the Act". In turn, 16 CFR § 801.1(f)(2) (2007) defines "convertible voting security" as "a voting security which presently does not entitle its owner or holder to vote for directors of any entity" (emphasis added).

The general rule thus seems to be that convertible shares are subject to anti-trust reporting requirements only at the time of their conversion to voting status. Non-voting preferred shares such as those at issue in CET $v$ Sanlam would seem to be exempt upon acquisition from the HSR Act's notification and waiting requirements. However, before such shares could be converted into voting shares, the HSR Act notice and waiting period requirements would have to be satisfied (assuming the transaction otherwise met the HSR Act's jurisdictional requirements).

As stated above, given that the imposition of a "mid-stream" notice and waiting period after a triggering event would introduce substantial uncertainty, for example by impeding a shareholder's ability to protect her interests by voting her shares promptly, one open question is how parties in practice actually treat shares with automatic conversion triggers (such as the dividend default in CET v Sanlam). One possibility is that parties might observe the notification and waiting period requirements for convertible preferred shares at the time of acquisition of such shares, even though a filing would not formally be required at that time.

\subsection{The Clayton Act and relevant case law}

As indicated in the previous section of this paper, acquisitions of non-voting preference shares are typically exempt from the reporting requirements of the HSR Act.

Such acquisitions would, however, still be subject to the broad prohibitions of section 7 of the Clayton Act, which provides in pertinent part that:

[n]o person engaged in commerce or in any activity affecting commerce shall acquire, directly or indirectly, the whole or any part of the stock or other share capital and no person subject to the jurisdiction of the Federal Trade Commission shall acquire the 
whole or any part of the assets of another person engaged also in commerce or in any activity affecting commerce, where... the effect of such acquisition may be substantially to lessen competition, or to tend to create a monopoly ${ }^{40}$.

Transactions can violate the Clayton Act without an acquiring party establishing control over a target. In Denver \& Rio Grande W. R.R. Co. $v$ United States ${ }^{41}$, the United States Supreme Court held that:

[a] company need not acquire control of another company in order to violate the Clayton Act. ... Section 7 [of the Clayton Act] proscribes acquisition of 'any part' of a company's stock where the effect 'may be substantially to lessen competition, or to tend to create a monopoly'.

In support of this proposition, the Court cited its earlier decision in United States v E. I. $d u$ Pont de Nemours \& $\mathrm{Co}^{42}$, where it had held that du Pont's acquisition of a 23 per cent voting stake in General Motors violated the Clayton Act because, inter alia, du Pont had purposely purchased the stock to "entrench itself as the primary supplier of General Motors' requirements for automotive finishes and fabrics".

Under certain circumstances, acquisition of non-voting shares may also contribute to a finding of "substantially ... lessen[ing] competition, or ... tend[ing] to create a monopoly" under the Clayton Act. In a 1961 follow-up case (" $d u$ Pont II") to the $1957 d u$ Pont decision cited above, the Supreme Court held that du Pont's proposal to transfer its voting rights in its General Motors stock to du Pont shareholders would not neutralise the earlier violation. The Court stated:

The divestiture only of voting rights does not seem to us to be a remedy adequate to promise elimination of the tendency of du Pont's acquisition offensive to $\S 7$ [of the Clayton Act]. Under the [proposed remedy], two-thirds of du Pont's holdings of General Motors stock will be voted by du Pont shareholders. ... Common sense tells us that under this arrangement there can be little assurance of the dissolution of the intercorporate community of interest which we found to violate the law. The du Pont shareholders will ipso facto also be General Motors voters. It will be in their interest to vote in such a way as to induce General Motors to favor du Pont, the very result which we found illegal on the first appeal. ${ }^{43}$

Admittedly, $d u$ Pont II dealt with the adequacy of a remedy for a prior violation, rather than an initial finding of anticompetitive effect, so it is not directly on point. As the Court there explained:

The burden is not on the Government to show de novo that a 'pass through' of the General Motors vote, like du Pont's ownership of General Motors stock, would violate $\$ 7$. . . It need only appear that the decree entered leaves a substantial likelihood that the tendency towards monopoly of the acquisition condemned by $\S 7$ has not been satisfactorily eliminated. ${ }^{44}$

The United States Court of Appeals for the Sixth Circuit recently considered a similar factual situation, but in the absence of a prior violation. In United States v Dairy Farmers of America, $I n c^{45}$., the court upheld, against a motion for summary judgment, the government's complaint that an ownership agreement between DFA, a dairy farm cooperative, and Southern Belle, a milk processing plant, had violated the Clayton Act. After the government had filed its complaint, but prior to DFA's motion for summary judgment, DFA transferred its 50 per cent common (voting) ownership interest in Southern Belle into a "non-voting preferred capital interest", such that voting control then rested solely with AFLP (DFA's partner, which held the remaining 50 per cent of common voting stock). Citing $d u$ Pont II, the court found that such an arrangement could potentially violate the Clayton Act:

While DFA does not have a voting interest [in Southern Belle] under the revised agreement, [DFA] may leverage its position as Southern Belle's financier to control or influence Southern Belle's 
decisions. Although Southern Belle may seek alternative financing, the United States correctly points out that such a switch may be a negative signal to other potential lenders. In other words, Southern Belle may be "locked in" to a relationship with DFA, a fact that DFA could use to its advantage. As a result, DFA's financial relationship with Southern Belle could lead to anticompetitive effects. ${ }^{46}$

However, as in $d u$ Pont II, the court noted that a commonality of economic interest between DFA and residual owner AFLP muted the isolating value of DFA's divestiture of voting rights:

DFA purportedly cured any potential antitrust problems in the agreement with Southern Belle by giving all of its voting rights to AFLP. This cure, however, ignores the fact that AFLP and DFA have closely aligned interests to maximize profits via anticompetitive behavior. As [government witness] Professor Scott explained, '[t]o think that the nature of the interaction between the two dairies will not change is naive, because that would be contrary to the economic incentive of all parties' ${ }^{47}$

Thus, although neither $d u$ Pont II nor Dairy Farmers of America is squarely on point with CET v Sanlam (which, for instance, did not involve a voting entity with common economic interests to Sanlam), it seems reasonable to conclude that a US court would, under certain circumstances, consider non-voting preference shares in analysing anti-competitive effect under the Clayton Act. (As a practical matter, US courts may not be faced with many such cases, given that acquisitions of non-voting shares are exempt from the reporting and other requirements of the HSR Act.) But, on a theoretical level at least, to the extent that $C E T v$ Sanlam brings non-voting preference shares within the general bailiwick of South African anti-competitive effects analysis (from which calculus such shares previously might have been excluded), CET $v$ Sanlam could be viewed as consistent with the basic approach of US courts and the Clayton Act.

One important caveat is that the exemption of convertible shares from the HSR Act reporting does not directly involve a test for corporate control, as the HSR Act applies to the acquisition of "any voting securities" in transactions meeting that Act's jurisdictional thresholds. The acquisition of control (and the relevance of non-voting shares to the control calculation) evidently plays a more central role in South African law, given the explicit role of "control" in the Competition Act's definition of "merger", section 12(1).

\section{5}

\section{Whether the triggering of voting rights for non-voting preference shares would require a further notification}

According to the Tribunal's rulings in cases such as Ethos and Caxton, an increase in the control of a controlling firm does not require further notification from the competition authorities. Neither does a change from one kind of control (e.g. share ownership) to another (say, voting rights).

The Tribunal's statements in Ethos are apposite $^{48}$ :

Does this mean that Ethos might have to notify again if it crosses some other threshold in section 12(2) that it presently does not enjoy now? For instance, if it was able to control or veto the appointment of the majority of the directors of the firm, a power that, as we have seen, it does not presently enjoy.

The answer to that question is no. A change of control is a once-off affair. Even if a firm has notified sole control at a time when that control is attenuated in some respects by other shareholders and it later acquires an unfettered right, provided that sole control has been notified and that this formed the basis of the decision, no subsequent notification is required. ${ }^{49}$

The Tribunal has, however, held that there is a notifiable merger in the event of a change from joint to sole control. ${ }^{50}$ The same principle has been acknowledged by the European Commission in ICI/Tioxide. ${ }^{51}$ In that case, the 
European Commission held that "decisive influence exercised solely is substantially different to decisive influence exercised jointly, since the latter has to take into account the potentially different interests of the other parties concerned". As a consequence of this change in the level of control, the European Commission found that a concentration (or merger) had occurred.

Thus, if after the acquisition of preference shares by a financial institution there is a subsequent change from joint to sole control consequent upon the triggering of voting rights in the preference shares, there could potentially be a need for a further notification.

In CET v Sanlam, there were no facts supporting such a scenario. There was nothing to suggest that any other firm had control, as envisaged by s 12(1) or s 12(2) of the Competition Act, prior to March 2002, or at any time thereafter. The remaining shareholdings were seemingly relatively small and widespread. That principle was accordingly not applicable.

CET nevertheless tried to argue on appeal before the CAC that the situation in that case was analogous. According to CET, there should be a further notification when there is a change in the "quality of control", or where there is a change from "deemed control" to "actual control".

Similar contentions were, however, rejected by the Tribunal, in our opinion, with good reason.

The argument for a further notification appears to overlook the nature of the enquiry that would take place when the competition authorities considered the transaction after its conclusion, and before its initial implementation. Postulate what would have happened had the Tribunal had to approve the Sanlam / Sancino agreement before Sanlam could take possession of the Sancino shares. That evaluation would have involved a consideration of whether there was likely to be any substantial prevention or lessening of competition had Sancino defaulted on its obligations and Sanlam had been, as a consequence, able to exercise the conditional voting rights attaching to the preference shares. There would therefore be no need to consider that question again if and when the default occurred. In the words of the Tribunal ${ }^{52}$, no additional potential threat to competition would have come into being.

A case such as CET $v$ Sanlam is therefore not really analogous to one in which an entity that jointly controls a firm increases its shareholding so that it assumes sole control. Instead, the factual matrix is more analogous to the one addressed in Ethos. Sanlam had control of Sancino beginning in March 1998 by virtue of beneficially owning more than one-half of the issued share capital of that firm, albeit the control was attenuated in some respects. In March 2002, the restraints on the control were, as a fact, removed when the voting rights were (potentially only provisionally) triggered. However, Sanlam enjoyed no greater legal rights: it still owned the same number of preference shares, with the same rights and privileges.

It would also not be justifiable to classify Sanlam's pre-March 2002 control as "deemed control". The Competition Act does not distinguish between deemed and actual control in s 12(2), or, for that matter, s 12(1). Instead, it regards each of the scenarios covered by s 12(2) as involving the acquisition of control. (See also Distillers at 45-46, where the Court rejected the argument that s 12 was concerned only with actual control.) It is thus of no materiality from a competition law perspective if a firm that has control as envisaged in s 12(2)(a), but not $\mathrm{s} 12(2)(\mathrm{b})$, also acquires control in the form contemplated by the latter section.

There is a further consideration, which relates to how one acquires or establishes control for the purposes of s 12 of the Competition Act.

Section 12(1)( $a$ ) of the Competition Act defines the occurrence of a merger with reference to the time when a party "acquires" or "establishes" control. Despite the looseness of this terminology, it seems that the section would, in the context of the Competition Act as a whole, connote the vesting of control through a deliberative act pursuant to a transaction of some kind. ${ }^{53}$

Thus, where a transaction is concluded on terms which may, without further consensus by the parties, result in one of them acquiring control of the other, as defined in s 12, the transaction 
is immediately notifiable, even though the circumstances which will trigger the vesting of control may occur only in the future or may, in fact, never occur. ${ }^{54}$

If this were not so, it would not be possible, in cases where the triggering event occurs without further consensus, to observe the Competition Act's injunction against the "implementation" of a merger without approval. By way of illustration, in CET v Sanlam the implementation of the agreement involved the issuing of shares to Sanlam on terms which were incorporated by way of an amendment to Sancino's articles of association. Once that was done, Sanlam became the holder of shares which, in circumstances beyond its control and as a result of terms incorporated not only in the agreement but also in Sancino's articles, might result in Sanlam's being entitled to vote a majority of the shares at a general meeting of Sancino.

Sanlam's entitlement to vote the shares thus flowed from an already implemented agreement. Although CET wished to interdict Sanlam from exercising its voting rights, this did not and could not change the fact that, in terms of the agreement as read with the articles, Sanlam was already entitled to vote the majority of the shares. This was a consequence of the implementation of the transaction in March 1998, and not a consequence of any act of implementation in March 2002.

It must be emphasised that it is the entitlement to vote, and not the exercise of the entitlement, which constitutes the control envisaged in $\mathrm{s}$ 12(2)(b) (a section which, it will be recalled, provides that a person controls a firm if he "is entitled to vote a majority of the votes that may be cast at a general meeting of the firm, or has the ability to control the voting of a majority of those votes ..." (emphasis added)). Accordingly, when one speaks of the "implementation" of a merger in this context, one is not talking about the exercise of the voting power. Even if a person with control declines to exercise it, this does not mean that the transaction is not a merger. One is, in fact, talking about the acquisition of the entitlement to vote. As the entitlement in CET $v$ Sanlam flowed ineluctably (without further deliberative action by Sanlam) from the terms of the agreement and the articles of association, the "implementation" must have occurred in March 1998. (In the same way, a merger as contemplated in $\operatorname{si2}(2)(a)$ is "implemented" when the acquirer becomes the beneficial owner of the shares, not only when the acquirer, for example, starts to receive dividends).

It was also explained earlier how it would be unfair for the competition authorities to disapprove a transaction years after it had been concluded. Had the preferent shareholder not obtained voting rights in the event of default, it might well not have been willing to subscribe for the preference shares in the first place. To require the holder of preference shares to subject itself to a second notification prior to exercising voting rights which were secured precisely in order to protect the shareholder's interests in such circumstances would be unduly onerous and inequitable, and would provide a severe disincentive to the acquisition of preference shares.

\section{6}

\section{The road ahead}

Given the terms in which s 12(2) of the Competition Act is framed, we are of the view that the Tribunal's decision in CET v Sanlam that there was a merger in 1998 when Sanlam became the beneficial owner of over 76 per cent of Sancino's issued share capital was correct. However, despite our conclusion, a number of important and practical issues arise in consequence of the Tribunal's finding.

One of the principal questions raised by $C E T v$ Sanlam is how, within the strictures of the text of the Competition Act, to minimise any potential costs of adopting a broad interpretation of the jurisdictional and threshold tests for review of notifiable mergers pursuant to the Competition Act (i.e., possible over-inclusive competition law regulation) while avoiding establishing a framework so stringent that too few transactions are reviewed (i.e., under-inclusive regulation).

The position that non-voting preference shares can confer control under the Competition Act has serious ramifications. Some of these implications are mentioned below. 
(1) It may jeopardise the ability of companies to raise funding by issuing non-voting preference shares.

(2) It may be viewed as out of kilter with the Commission's stance in relation to other forms of funding, such as where a bank acquires an asset or a controlling interest in a firm in the ordinary course of its business of providing finance for which it obtains collateral or security. In these circumstances, notification is required neither at the time of entering into the relevant transaction nor immediately upon default ${ }^{55}$.

(3) As noted above, an extension of CET $v$ Sanlam could potentially chill certain other types of transactions and business activity in addition to non-voting preference shares.

If the Tribunal's approach in CET $v$ Sanlam endures (and perhaps is expanded to other forms of non-voting financing), the legislature or the competition authorities may be motivated to consider formalising an ownership "safe harbour" mechanism similar to that contained in the Commission's Practitioner Update for secured transactions involving banking and financial services entities ${ }^{56}$. Despite a relatively expansive interpretation of the jurisdictional and threshold "control" test in the Competition Act, the creation of other bright-line "safe harbours" to allow firms to organise their financing arrangements without being susceptible to excessively onerous merger review will probably also need to be considered. In this enquiry, the identification of other kinds of financing used in South Africa and the delineation of principled distinctions between them for purposes of determining whether the control pre-requisite of the merger review test under the Competition Act is satisfied will no doubt be instructive.

\section{Endnotes}

1 [2006] 1 CPLR 410 (CT), Case No. 05/X/Jan06; judgment handed down on 15 March 2006 (per Reyburn TM, Lewis TC and Bhoola TM concurring)

2 At par. 8.

3 At paragraph 60 of its determination.
4 If there is not considered to be a merger for competition purposes when the preference shares are first acquired, there can be little question that there would be a direct or indirect acquisition of control when voting rights are acquired with respect to those preference shares as a result of a default. That scenario accordingly need not be addressed.

5 [2001]-[2002] CPLR 36 (CAC) at 43j.

6 Henochsberg on the Companies Act at 170.

7 See s 75(1)(i) of the Companies Act, a section which deals with the power of companies to alter their "share capital".

8 See s 194 of the Companies Act.

9 See items $8(c)$ and $37(c)$ of Schedule 3 and items 8 and 9 of Schedule 4.

10 Vol 1 at 5-175.

11 Par. 47.

12 Par. 47.

13 Regarding the test for simulated transactions, see Zandberg v van Zyl 1910 AD 302 at 309 and Erf 3183/1 Ladysmith (Pty) Ltd v CIR 1996 (3) SA 942 (A) at $952 \mathrm{C}$.

14 Par. 44.

15 This accords with what the Tribunal said in the Ethos case at paras 37-42, commenting on the impracticality of requiring the Commission to enquire into every change in shareholder relations, an observation made in the context of arrangements between shareholders pertaining to voting.

16 [2003] 2 CPLR 371 (CT) at par. 32.

17 [2004] 1 CPLR 217 (CT) at par. 29.

18 At par. 30-31.

19 The Ethos case at par. 35, 42, and Caxton $v$ Naspers at par. 43.

20 Par. 52.

21 See 46b.

22 See also the comments of Davis JP in Distillers at 46f: "the purpose of merger control envisages a wide definition of control, so as to allow the relevant competition authorities to examine a wide range of transactions which could result in an alteration of the market structure and in particular reduce the levels of competition in the relevant market”.

23 At par. 29, in the passage quoted above.

24 See also Distillers at 46e, where Davis JP quotes from Richard Whish (Competition Law 4ed at 742 ) to the effect that "merger control is not, or not only, about pre-emptively preventing a merged entity from abusing its dominant position in the future; it is also about maintaining a market structure that is capable of producing the kind of outcome that follows from competition." 
25 At par. 63.

26 Par. 64.

27 See Practitioner Update issue The Application of the Merger Provisions of the Competition Act 89 of 1998, as amended, to Risk Mitigation Financial Transactions ("The Financial Transactions Practitioner Update"). However, this provision is similar to Article 3(5) of the Council Regulation (EC) No. 139/ 2004 of 20 January 2004 on the Control of Concentrations between Undertakings [OJ 2004, No. L 24/ 1] ("the Merger Regulations"), which provides that

A concentration shall not be deemed to arise where: (a) credit institutions or other financial institutions or insurance companies, the normal activities of which include transactions and dealing in securities for their own account or for the account of others, hold on a temporary basis securities which they have acquired in an undertaking with a view to reselling them, provided that they do not exercise voting rights in respect of those securities with a view to determining the competitive behaviour of that undertaking or provided that they exercise such voting rights only with a view to preparing the disposal of all or part of that undertaking or of its assets or the disposal of those securities and that any such disposal takes place within one year of the date of acquisition; that period may be extended by the Commission on request...

28 Published in [1989] OJ C66/5.

29 Article 3 of the Merger Regulations provides that a concentration occurs pursuant to an acquisition of control. Article 3(2) of the Merger Regulations provides guidance on the meaning of control, stating inter alia that "...control shall be constituted by rights, contracts or any other means which, either separately or in combination and having regard to the considerations of fact or law involved, confer the possibility of exercising decisive influence on an undertaking, in particular by: (i) ownership or the right to use all or part of the assets of an undertaking; (ii) rights or contracts which confer decisive influence on the composition, voting or decisions of organs of an undertaking".

30 ICI/ Tioxide [1991] 4 CMLR 792.

31 Case M.259 (Dec. of 27 November 1992).

32 See 15 U.S.C. $\$ \S 1-7$.

33 See 15 U.S.C. $\$ \$ 12-27,29$ USC. $\$ \$ 52-53$.

34 See 15 U.S.C. $\$ 18$ a.

3515 U.S.C. $\S 18$.

36 This paragraph and the following paragraph draw on Kenneth R. Logan \& Jack D’Angelo, US Merger
Control, Mar. 3, 2003, available at http://www. stblaw.com/content/Publications/Publication14_ $0 . p d f$.

3715 U.S.C. $\S 18 \mathrm{a}(\mathrm{a})$.

$38 I d . \S 18 \mathrm{a}(\mathrm{b})(3)(\mathrm{A})$ (emphasis added).

39 Id. $\S 18 \mathrm{a}(\mathrm{c})(2)$.

40 15 U.S.C. $\S 18$ (emphasis added).

41387 U.S. 485, 501 (1967).

42353 U.S. 586, 606 (1957).

43 United States v E.I. du Pont de Nemours \& Co., 366 U.S. 316, 331 (1961) (du Pont II).

44 Id. at 331-332.

45426 F.3d 850, 861-62 (6th Cir. 2005).

46426 F.3d at 861-63.

$47 \quad 426$ F.3d at 862.

48 (supra) at par. 36-37.

49 See also Caxton v Naspers (supra) at paras 42, 44 \& 45; Brassey et al Competition Law 2002 p. 239.

50 See Iscor Limited and Saldanha Steel (Pty) Ltd (67/LM/Dec01.

51 European Commission IV/M0023, decision of 28 November 1990.

52 At par. 60 of its determination.

53 There are a number of contextual considerations that favour this view: (i) Section $12(1)(b)$ refers to the manner of "achieving" a merger, and all the forms given as examples in $\mathrm{s} 12(1)(b)$ are instances of bilateral or multilateral transactions. (ii) The Competition Act throughout speaks of the "parties" to a merger. (iii) With reference to mergers, the Competition Act defines the terms "acquiring firm" and "target firm". These definitions are based on the acquisition or establishment of control "as a result of a transaction in any circumstances set out in s12". (iv) In regulating the important aspect of retrospectivity, the legislature in items $4 \mathrm{~A}$ to $4 \mathrm{C}$ of schedule 3 refers to the date on which a "transaction" takes place, and envisages that it is the "transaction" which is notifiable. (v) The Competition Act prohibits the parties to a merger from "implementing" it pending approval $(\mathrm{s} 13 \mathrm{~A}(3)$; $c f \mathrm{~s} 13(4))$. This means that a "merger" must be something which exists and can be identified separately from its implementation. In other words, a "merger" is not the factual acquisition of control. It is the transaction pursuant to which control (perhaps at a later time) is acquired.

54 Cf. Ethos at par. 41.

55 See The Financial Transactions Practitioner Update.

56 See endnote 32 hereof and accompanying text. 